\title{
COMPLICITY AND THE DOCTRINE OF "COMMAND LIABILITY” FOR COMMITTING WAR CRIMES
}

\begin{abstract}
The article analyzes the mechanisms of bringing the servicemen of the opposing party of the armed conflict to criminal responsibility through the doctrines of "joint criminal enterprise" and "command responsibility", which are dealt with International criminal law considering that the acts committed by this category of persons are usually subject to investigation by international bodies of criminal justice on the basis of definitions developed by international practice. The analysis carried out by the author enables to propose scientifically substantiated recommendations on the qualifications of acts committed by servicemen of the opposing party of the armed conflict that constitutes corpus delicti of various war and international crimes.
\end{abstract}

Keywords: international crimes, international criminal law, International Criminal Court, qualification of war crimes.

The specificity of war crimes lies in the fact that such acts are planned, organized, encouraged, instigated, or, less likely, are not prevented, are tolerated or are not able to be suppressed by persons who hold the highest political and military posts in a State. In fact, the commission of war crimes would not be possible without the participation of high-ranking officials, since it is they who develop plans and give commands, therefore such persons should bear more responsibility than subordinates who directly committed the act (UN International Law Commission, 1996).

In the course of the investigation of war crimes committed by an opposing party of an armed conflict, it is necessary to take into account the volume, nature, system, tactical and technical characteristics and locations of the weapons used, the degree of thoroughness of the analysis of the selected ground targets, the number of personnel involved, adherence to the procedure established for this, the extent of ignoring the norms of international humanitarian law, the degree of military, political and propaganda training, planned, organized and sanctioned directly by the highest command personnel. Therefore, it would be a paradox to punish only the executors of criminal orders, specific servicemen, artillerymen, snipers, intelligence officers, etc. The commanders who gave the criminal orders should also be held responsible for these crimes.

The scientific community on the creation and application of the Joint criminal enterprise doctrine was divided, inter alia, into diametrically opposed positions in assessing the effectiveness of the practical application of the JCE doctrine under consideration (Dershowitz, 2012, 
p. 23; Poweles, 2004, pp. 606-619).

Although the JCE doctrine is the most complicated and controversial theory in International criminal law, in our opinion, International criminal law provides for individual criminal responsibility of a person both for the direct commission of international crimes and for other complex forms of complicity aimed at realizing a common goal, plan or project, including the indirect participation to facilitate the commission of a crime, where the person does not have to share the intent of the accomplices.

The provisions that the person who planned, instigated, ordered, committed or otherwise aided or abetted in planning, preparing or committing a crime is personally responsible for this crime are reflected in Article 6 of the London Charter, Article 5 of the Charter of the Tokyo Tribunal, respectively in paragraph 13 of principle VII and Article 2 (3) of the Drafts of Code of Crimes against the Peace and Security of Mankind (1954) and (1996), in Article 7 (1) of the Statute of the International Criminal Tribunal for the Former Yugoslavia (hereinafter ICTY) (UN Commission of Experts, 1992), (ICTY Statute, 1993); in Article 6 (1) of the Statute of the International Criminal Tribunal for Rwanda (hereinafter ICTR) (ICTR Statute, 1994), in Article 6 (1) of the Statute of the Special Court for Sierra Leone, in Article 29 of the Law on establishing the Extraordinary Chambers in the Courts of Cambodia for the consideration of crimes committed during the existence of Democratic Kampuchea, in section 14 (3) of the Regulation of the UN Transitional Administration in East Timor No. 2000/15, Article III (e) of the Convention on the Prevention and Punishment of the Crime of Genocide (Adelkhanyan, 2006).

But the most detailed list of types of complicity in an international crime is listed in Arti- cle 25 (3) of the Rome Statute of the International Criminal Court (hereinafter ICC) (Matveeva, 2015, pp. 54-64; Bothe, 2002; Aldrich, 2000; Cryer, 2005).

Thus, in accordance with Article 25(3) of Rome Statute of the ICC, a person shall be subject to criminal responsibility and punishment for a crime within the jurisdiction of the Court if that person: a) commits such a crime individually, jointly with another person or through another person, regardless of whether the other is subject to a person of criminal responsibility; b) orders, instigates or induces the commission of such a crime, if this crime is being committed or if there is an attempt on this crime; (c) in order to facilitate the commission of such an offence, aiding, abetting or in any other way facilitating its commission or attempt on it, including providing the means for its commission; d) in any other way contributes to the commission or attempted commission of such a crime by a group of persons acting with a common purpose.

Such assistance must be provided intentionally and either: (i) in order to support the criminal activity or criminal purpose of the group where such activity or purpose is related to the commission of an offence within the jurisdiction of the Court; or (ii) in the knowledge of the intent of the group to commit an offence; e) in relation to the crime of genocide, directly and publicly instigate others to commit genocide; f) attempts to commit such a crime by taking an action that constitutes a significant step in its commission, but the crime remains unfinished due to circumstances beyond the control of the person concerned. However, a person who refuses to attempt to commit a crime or otherwise prevents the completion of a crime shall not be punished in accordance with this Statute for attempting to commit that crime if that person has completely 
and voluntarily abandoned the criminal purpose".

Thus, 5 types of participation in a crime are described: direct commission, ordering, planning, instigating, as well as aiding and abetting.

Direct commission of a crime corresponds to the concept of "perpetrator" in Armenian criminal law. In this case, the act can be expressed both in action and in inaction or in insufficiently effective action. Thus, in the judgments of the ICTY Trial Chamber in the cases of Kordić and Čerkez, Kvoćka, Vasilyević, Kunarac, as well as in the judgments of the ICTR in the Rutaganda, Musema, Semanza cases, the direct commission of a crime requires the direct personal or physical participation of the accused in the actual actions that constitute a crime ${ }^{1}$, and the ICTY decision in the Stakić case notes that the accused must participate, physically or otherwise, directly or indirectly, in the material elements of the crime, which are expressed in positive actions or omissions based on the duty to act, individually or in association with others. The accused should not be directly involved in all aspects of the alleged criminal behaviour. ${ }^{2}$

Criminal ordering: commanders and other chiefs are criminally responsible for war crimes committed on their orders, which are provided for by the legislation of many States, including

\footnotetext{
See: ICTY. Judgment of the Trial Chamber in the Kordić and Čerkez case, 26 February 2001 (IT-95-14 / 2-T), paragraph 376. ICTY. Judgment of the Trial Chamber in the Kvoćka case, 2 November 2001, paragraph 251; Judgment of the Trial Chamber in the Vasiliević case, 29 November 2002, paragraph 62; Judgment of the Trial Chamber in the Kunarac et al. case, 22 February 2001, paragraph 390. See also: ICTR. Judgment of the Trial Chamber in the Rutaganda case, 6 December 1999, paragraph 41; Judgment of the Trial Chamber in the Musema case, 27 January 2000, paragraph 123; Judgment of the Trial Chamber in the Semanza case, 15 May 2003, paragraph 383.

2 See: ICTY. Judgment of the Trial Chamber in the Stakić case, 31 July 2003, paragraph 439.
}

Article 47 of the Criminal Code of the Republic of Armenia (hereinafter referred to as the RA CC) (Criminal Code of the Republic of Armenia, 2003). The practice of States establishes this rule as a rule of customary international law (rule 152) - applicable regardless of the type of conflict and has found its expression in a significant number of ICTY and ICTR judgments. ${ }^{3}$ A criminal ordering is a war crime ${ }^{4}$ committed by a commander or other superior, i.e. persons who, due to their official position, have the ability to give orders and expect that such orders will be executed by people under their control. Thus, in the decision of the Trial Chamber in the Blaškić case, the ICTY stated that "there is no need for the order to be given in writing or in any other specific form. It can be explicit or implicit. The fact that the order was given can be proven through circumstantial evidence", for example, an analysis of the behaviour of the military units subordinate to the accused. Thus, for example, in the Galić case, considering the evidence of systematic sniper and artillery shelling of the civilian population of besieged Sarajevo, the Court found, "in sum, the evidence leads to the conclusion that General Galić, who, although being notified of the crimes committed by his subordinates, over which he had full control, and who consistently and over a long period of time was unable to prevent the commission of crimes and

3 See, for example: ICTY. Judgments in cases Delalić et al, Blaškić, Kordić anc Čerkez, Krstić. See also: ICTR. Judgments in Akayezu, Kayishema, Ruzindana cases.

4 Article 49 of the First Geneva Convention, Article 50 of the Second Geneva Convention, Article 129 of the Third Geneva Convention, Article 146 of the Fourth Geneva Convention, Article 28 of the Hague Convention for the Protection of Cultural Property, Article 2 of the 1996 Draft Code of Crimes against the Peace and Human Security establish the responsibility of the superior official who gave the order to commit an international crime.

5 See: ICTY, Judgment of the Trial Chamber in the Blaškić case, 3 March 2000, paragraph 281. 
punish those responsible despite this knowledge, promoted a campaign of unlawful violence against civilians through orders passed down the chain of a campaign with the primary goal of spreading terror among the civilian population of Sarajevo. ${ }^{6}$ At the same time, the execution of the order of the chief does not relieve the subordinate from criminal responsibility if the subordinate knew that the action he was ordered to perform is illegal or should have known about it due to the clearly illegal nature of this action.

In our opinion, most war crimes are clearly illegal, and such a question will never arise. This principle is called the "principle of responsibility of the subordinate" or "the principle of the inadmissibility of reference to the order of a superior chief'. State practice establishes the principle of subordinate responsibility as a rule of customary international law. The inadmissibility of reference to order is established by the Charters of the Nuremberg and Tokyo Tribunals, Article 8 London Charter, Article 4 (b) of the Law of the Control Council number 10, Article 6 of the Statute of the Military Tribunal for the Far East, Nuremberg Principle IV, Article 7 (4) of the ICTY Statutes, Article 6 (4) ICTR Section 21 Ordinance Establishing a Special Panels for Serious Crimes in East Timor, Section 6 (4) Statute of the Special Court for Sierra Leone, Article 33 of the Rome Statute of the ICC. An analysis of this provision in the listed statutes shows that a person is exempted from criminal responsibility not because he has fulfilled a legally binding order for him, but because of the absence of a subjective element of the crime caused either by an error in law, or an error in a fact, or both factors together. This interpretation of the issue of responsibility for the execution of an order finds its

6 See: ICTY, Judgment of the Trial Chamber in the Galić case, 5 December 2003, paragraph 749. justification in the practice of states. The military regulations and the national law of most states speak of "clearly illegal orders" (Henkerts \& Doswald-Beck, 2006, pp. 721-725). This approach is also implemented in the RA Criminal Code. At the same time, there is also a practice that does not require the executor to know about the illegality of the order. Thus, in the Blaškic case, the ICTY Trial Chamber ruled that "it is irrelevant whether the illegality of the order was apparent on its face".?

However, this practice is not widespread and uniform enough to establish a rule of customary international law (Henkerts \& DoswaldBeck, 2006, p. 726). At the same time, in the decisions of the ICTY and ICTR Trial Chambers, respectively in the case of Kordić and Čerkez and in the case of Gakumbtsi, it is sufficient that the "chief-subordinate" relationship actually existed, i.e. that a person has de facto the political or military power to give orders, and a formal relationship of subordination is not required. ${ }^{8}$

Thus, a criminal order differs from such forms of participation in a crime as instigating, aiding and abetting by the presence of a sign of coercion, which a person exercises on the basis of either official or actual authority, or on the basis of the use or threat of physical violence. At the same time, the execution of the order of the superior does not relieve the subordinate from criminal responsibility if the subordinate knew that the action he was ordered to perform is illegal or should have known about it due to the clearly illegal nature of this action. The fact that

7 See: ICTY, Judgment of the Trial Chamber in the Blaškić case, 3 March 2000, paragraph 282.

8 See: ICTY. Judgment of the Trial Chamber in the Kordić and Čerkez case, 26 February 2001, paragraph 388: "No formal chief-subordinate relationship is required to establish an "order"' when it is demonstrated that the accused had the power to order". ICTR. Judgment of the Trial Chamber in the Gakumbtsi Case, 17 June 2004, paragraph 281. 
the person acted in pursuance of the order may be considered a mitigating circumstance. Most of the main war criminals who were convicted by the Nuremberg Tribunal cited the execution of the orders of their superiors as defence arguments. The Tribunal rejected the reference to the orders of the superiors and noted: "The provisions of Article 8 of the Charter are consistent with the laws of all nations. The fact that a soldier killed or tortured on orders in violation of international laws of war was never considered a defensive argument against charges of these atrocities. The very fact of the existence of an order can be exposed only as a mitigating circumstance when imposing a punishment".

State practice establishes the principle of subordinate responsibility as a rule of customary international law applicable to crimes, regardless of the type of conflict. It is closely linked to the rule that every combatant has a duty to disobey an unlawful order and to the imperative duty to comply with international humanitarian law (Henkerts \& Doswald-Beck, 2006, pp. 721-724, 631-635).

The same approach is implemented in Part 3 of Article 47 of the RA Criminal Code, that failure to comply with a clearly illegal order or instruction excludes criminal responsibility. The UN International Law Commission clarified that although the person issuing the criminal order bears special responsibility for the crime, "the guilt and inevitable role played by the subordinate in the actual commission of the criminal act cannot be ignored. Otherwise, the legal force and consequences of the prohibition of crimes under international law would be significantly weakened by the absence of any responsibility or punishment of the actual perpetrators of these hei- nous crimes, any factor deterring potential violators". 9

Planning refers to the substantial projecting (formulation or approval of a criminal plan) of the commission of a crime, both in the preliminary phases and in the phases of its execution ${ }^{10}$, which can be proven, including through circumstantial evidence ${ }^{11}$. To charge a person with planning, it must be proven that the crime was actually committed (Kibalnik \& Martirosyan, 2015; Guskova, 2012, p. 544).

Instigating is the inducement ${ }^{12}$ of another person through deliberate pushing, persuasion or another way of encouraging ${ }^{13}$ the commission of a crime, either by explicit or implicit behaviour, either action or inaction, but in the latter case, he must be endowed with the obligation to prevent the crime. ${ }^{14}$ Thus, mere presence at the scene of an atrocity may constitute incitement if the accused is a representative of the authorities and does nothing to prevent or stop the crime ${ }^{15}$

9 See: the project of the Code of crimes against peace and security of mankind, 1996, Article 5, Commentary, p. 3.

10 See: ICTY. Judgment of the Trial Chamber in the Blaškić case, 3 March 2000, paragraph 279. Judgment of the Trial Chamber in the Krstić case, 2 August 2001, paragraph 601. See also: ICTR. Judgment of the Trial Chamber in the Akayezu case, 2 September 1998, paragraph 480. Judgment of the Trial Chamber in the Rutaganda case, 6 December 1999, paragraph 37. Judgment of the Trial Chamber in the Musema case, 27 January 2000, paragraph 119; Judgment of the Trial Chamber in the Bagilisham case, 7 June 2001, paragraph 30.

11 See: ICTY. Judgment of the Trial Chamber in the Blaškić case, 3 March 2000, paragraph 279.

12 See: ICTY. Judgment of the Trial Chamber in the Krstić case, 2 August 2001, paragraph 601. Judgment of the Trial Chamber in the Blaškić case, 3 March 2000, paragraph 280 .

13 See: ICTY. Judgment of the Trial Chamber in the Orić case, 30 July 2006, paragraph 271 , also see the paragraph 274.

14 See: ICTY. Judgment of the Trial Chamber in the Orić case, 30 July 2006, paragraph 273. Also see: ICTR. Judgment of the Trial Chamber in the Rutanga case, 6 December 1999, paragraph 41.

15 See: ICTY. Judgment of the Appeal Chamber in the Tadić case, 15 July 1999, paragraph 198. See also: 
(Greenwood, 1996; Henkaerts \& Doswald-Beck, 2005, p. 689). In the Aleksovsky case, the ICTY argued that a person's position of power must be considered an important sign for establishing that mere presence constitutes an act of intentional participation. The presence at the scene of a crime of a person who has undeniable power over the perpetrators of an unlawful act, under some circumstances, can be interpreted as an approval of their behaviour (the effect of "approving spectator" ${ }^{\prime 16}$ ). Instigating does not have to be "direct and public" or involve the presence of the instigator at the crime scene. The influence of the instigator can be carried out both directly and through intermediaries, both on a small and on a large group of people. ${ }^{17}$ Instigating differs from participation in a crime in the form of an order; it does not imply any subordinate relationship between the instigator and the direct perpetrator of the crime. At the same time, it is noted that the exercise of influence is hardly possible without a certain ability to exert influence on others. ${ }^{18}$

The criteria for aiding ${ }^{19}$ and abetting ${ }^{20}$ were defined by the ICTY in the Furundžija case,

Judgment of the Trial Chamber in the Kordic and Čerkez case, 26 February 2001, paragraph 387. Judgment of the Trial Chamber in the Blaškić case, 3 March 2000, paragraph 280.

16 See: ICTY. Judgment of the Trial Chamber in the Aleksovski case, 24 March 2000, paragraph 65. See also: ICTY. Judgment of the Trial Chamber in the Blaškić case, 3 March 2000, paragraph 284.

17 See: ICTR. Judgment of the Appeal Chamber in the Akayezu case, 1 June 2001, paragraphs 474-483. Also: ICTY. Judgment of the Trial Chamber in the Orić case, 30 July 2006, paragraph 273.

18 See: ICTY. Judgment of the Trial Chamber in the Orić case, 3 July 2006, paragraph 272.

19 Aiding corresponds with the notion of "physical aiding", which is characteristics of Armenian criminal law.

20 Abetting corresponds to the concept of "intellectual complicity" adopted in Armenian criminal law, which consists in facilitating the commission of a crime with advice, instructions, and also a promise made in advance to hide the offender. An intellectual accomplice only strengthens the determination to commit a crime, while the instigator by his actions induces such deter- where actus reus is an act or omission that consists of practical assistance, support or moral support that has a significant effect on the commission of a crime, and mens rea - knowledge that these actions help to commit a crime ${ }^{21}$. In the decisions of the ICTY and the ICTR, respectively, in the cases of Kvoćka et al, Akayezu, Ntakirutimana et $\mathrm{al}^{22}$, it is emphasized that aiding is helping someone through the provision of funds, and abetting is facilitating an illegal act, for the commission of which the abettor feels "sympathy" through actions like "encouragement" of the main culprit. Meanwhile, the contribution of an aider and abettor to the commission of a crime must be substantial, i.e. must have an actual impact on the commission of the crime (UN International Law Commission, 1996, p. 24). Moreover, for the onset of criminal responsibility, at least one of these forms of participation in a crime is sufficient. Article 25 (3) (c) of the Rome Statute prescribes that the purpose of aider and abettor should be in facilitating the commission of a crime. An aider and abettor should not share the intent of the main offender but must be aware of this intent and the main elements of the crime. ${ }^{23}$ At the same time, there

mination. "Aiding" generally refers to some form of physical assistance in committing a crime, but of a "secondary" nature, while "abetting" implies support or other form of moral coaxing.

21 See: ICTY. Judgment of the Trial Chamber in the Furundžija case, 10 December 1998, paragraph 249.

22 See: ICTY. Judgment of the Trial Chamber in the Kvoćka et al, 2 November 2001, paragraph 254. See also: ICTR. Judgment of the Trial Chamber in the Akayezu case, 2 September 1998, paragraph 484. See also: Judgment of the Trial Chamber in the Ntakirutimana and Ntakirutimana, 21 February 2003, paragraph 384.

23 See: Judgment of the Trial Chamber in the Furundžija case, 10 December 1998, paragraph 245. See also: Judgment of the Trial Chamber in the Aleksovski case, 24 March 2000, paragraph 162. Judgment of the Trial Chamber in the Vasilyević case, 29 November 2002, paragraph 71. See also: Judgment of the Trial Chamber in the Vasilyević case, 29 November 2002, paragraph 71 . 
is no requirement that the aider and abettor know exactly what kind of crime was being prepared and was actually committed. If a person knew that at least one of the many crimes was likely to be committed, and one of them is actually being committed, and he intended to facilitate the commission of such a crime, then that person is guilty as an aider or abettor. ${ }^{24}$

A person's guilt can be established on the basis of various circumstances, in particular, such as the person's position as a superior and his presence at the crime scene. Moral or verbal support, or even mere presence at the crime scene, may in some cases be sufficient to conclude that the accused was involved in the crime. ${ }^{25}$ The act of assisting a crime, expressed in "aiding and abetting", can occur before, during, or after the crime is committed. It can take the form of providing the means to commit a crime or promises to take certain actions as soon as the crime is committed. Therefore, "the act contributing to the commission of the crime and the commission itself may be geographically and temporally distanced". ${ }^{26}$ Thus, in the Rutaganda case, the ICTR noted that the act of assistance might be geographically and chronologically unrelated to the actual commission of the crime ${ }^{27}$, and in the Tadic case, the ICTY noted that the aider and abettor are responsible for all the naturally occurring consequences of the criminal act. $^{28}$ The ICTY Appeals Chamber determined that the mere knowledge of an aider and abettor that his actions are helping to commit the underlying crime

24 See: ICTY. Judgment of the Trial Chamber in the Furundžija case, 10 December 1998, paragraph 246.

25 See: ICTY. Judgment of the Trial Chamber in the Aleksovski case, 25 June 1999, paragraph 62.

26 See: ICTY. Judgment of the Trial Chamber in the Tadić case, 7 May 1997, paragraph 687.

27 See: ICTR. Judgment of the Trial Chamber in the Rutaganda case, 6 December 1999, paragraph 43.

28 See: ICTY. Judgment of the Trial Chamber in the Tadić case, 7 May 1997, paragraph 692. is sufficient to establish guilt ${ }^{29}$ (Jones, 2000; Puzireva, 2014).

In the case of Nasser Orić, the ICTY Trial Chamber determined that incitement, in the sense of the term "instigation", differs from "aiding and abetting"; the former requires some influence on the main offender through pushing, persuasion or another way of stimulating the commission of a crime and must contain more than just facilitating the commission of the crime by the perpetrator, which may be sufficient to aiding and abetting. ${ }^{30}$

In this case, the inaction of the person, including the commander, can be willful and negligent. In the case of deliberate inaction, the person (commander), knowing that his subordinate is committing or preparing to commit a crime, realizes that if he does not interfere, the natural and foreseeable consequence will be the commission of a crime and being obliged to suppress the actions of the subordinate, such inaction has a significant effect and support crimes, which may be perceived by subordinates as approval of their crimes. Thus, the objective side of aiding and abetting is committed, but in our opinion, in such a situation, the actions of the person (commander) should be qualified as a co-perpetrator of this crime. This approach is implemented in the decisions of the ICTY Trial Chambers in the cases of Kordić and Čerkez, Blaškić, Vasiljević. $^{31}$ In a situation where a person (commander), knowing about the crimes committed

29 See: ICTY. Judgment of the Appeal Chamber in the Vasiljević case, 25 February 2004, paragraph 102.

30 See: ICTY. Judgment of the Trial Chamber in the Orić case, 30 July 2006, paragraph 271; also see: paragraph 274.

31 See: ICTY. Judgment of the Trial Chamber in the Kordić and Čerkez case, 26 February 2001, paragraph 371; ICTY. Judgment of the Trial Chamber in the Vasiljević case, 29 November 2002, paragraph 70; ICTY. Judgment of the Trial Chamber in the Blaškić case, 3 March 2000, paragraph 284. 
by subordinates, refuses to punish and encourages subordinates in the form of submission to military awards, promotions and other measures, stimulates further crimes, then such an act, in our opinion, can be qualified as a more active instigating.

Thus, in the decision of the ICTY Trial Chamber in the case of General Radislav Krstić, inaction was clearly demonstrated, which constituted a form of aiding and abetting. The court found that the accused did not order the murders. Neither he nor any of his subordinates personally participated in the murders and was not at the scene of the murders. However, he allowed his commander, General Mladić, to use the personnel and vehicles of his corps to prepare massacres (to transport future victims from places of detention to places of executions; for the illegal expulsion of women and children, etc.). In addition, although he gave an order not to harm Muslim refugees, he took no action to ensure that the order was carried out. ${ }^{32}$

In International humanitarian law, separately from other forms of compliance, is also prescribed "command responsibility doctrine", which, in essence, is a form of the commander's responsibility for his own inaction or omission, in a context where international law imposes a positive obligation to act, rather than for the actions of the perpetrators. In accordance with this doctrine, commanders and other superiors are criminally responsible in cases of crimes committed by their subordinates if they knew or should have known that their subordinates intend to commit or are committing such crimes, but did not take all necessary and reasonable measures within the limits of their authority to prevent them, or, if such crimes have already been

32 See: ICTY. Judgment of the Trial Chamber in the Krstić case, 2 August 2001; ICTY. Judgment of the Appeal Chamber in the Krstić case, 19 April 2004. committed, to punish those who committed them. The responsibility of higher commanders for the crimes committed by their subordinates is due to the great power of commanders over subordinates and the ability to prevent violations of international humanitarian law, which are provided for in Article 86 (1) and Article 87 (1) of Additional Protocol I to the Geneva Conventions, in military charters, in the legislation of a number of States, including those that are not parties to Additional Protocol I. Moreover, the practice of States establishes this type of responsibility as a rule of customary international law, regardless of the type of conflict. Such a norm is reflected in Article 7 (1) of the Statute of the International Criminal Tribunal for the Former Yugoslavia (hereinafter ICTY), in Article 6 (3) of the Statute of the International Criminal Tribunal for Rwanda (hereinafter ICTR), in Article 6 (3) of the Statute of the Special Court for Sierra Leone, in section 16 of the Regulation of the UN Transitional Administration in East Timor No. 2000/15, in Article 29 of the Law on establishing the Extraordinary Chambers in the Courts of Cambodia for the consideration of crimes committed during the existence of Democratic Kampuchea, in Article 28 (1) of the Rome Statute of the ICC, and expressed itself in a variety of judgments, including in the cases of Delalić et al., Aleksovsky, Blaškić, Kunarac, Kordić and Čerkez, Krstić, Kvoćka, Strugar et al., Martić, Hadžhikhasanović et al., Karadžić and Mladić. ${ }^{33}$

33 See: ICTY Judgment of the Trial Chamber in the Kordić and Čerkez case, 26 February, 2001, paragraph 401; Judgment of the Trial Chamber in the Blaškić case, 3 March 2000, paragraph 294; Judgment of the Trial Chamber in the Delalić et al, 16 November 1998, paragraph 346; Judgment of the Trial Chamber in the Stakić case, 31 July 2003; Judgment of the Trial chamber in Blagojević case, 17 January 2005, paragraph 790. See also: ICTR. Judgment of the Trial Chamber in the Bagilishem case, 7 June 2001, paragraph 38 . 
To establish the responsibility of higher superiors for the actions of subordinates, the ICTY case law developed the main features of the responsibility of a superior in connection with the criminal acts of his subordinates: 1) the existence of a chief-subordinate relationship between the accused and the person who directly committed the crime; 2) the subjective side can be expressed from intent to criminal negligence and includes an obligatory element of "knowledge", i.e. the chief knew ${ }^{34}$ that the subordinates were going to commit, commit or have committed crimes (the so-called "factual knowledge") or the chief did not know, but should have known that subordinates are going to commit, commit or have committed crimes ${ }^{35}$ (so-called "constructive" knowledge), i.e. inaction of the chief; 3 ) inaction or omission of the commander in a situation where he could prevent a crime or punish those respon$\operatorname{sible}^{36}$, i.e. had the opportunity and obligation to take all necessary measures to prevent or suppress the crimes of his subordinates, including report the crime to a superior chief, the competent authorities, initiate an investigation or punish the perpetrator himself and did not take such measures; 4) the exercise of effective control (possession of power implies effective control if

34 ICTY. Kordić and Čerkez/trials/26 February 2001/ para.427. The term "knew" is understood as the realization that the relevant crimes were committed or should have been committed.

35 See: ICTY. Judgment of the Trial Chamber in the Delalić et al, paragraph 386; Judgment of the Trial Chamber in the Naletić and Martinović case, 31 March 2003, paragraph 70-71; Judgment of the Trial Chamber in the Blagojević case, 17 January 2005, paragraph 792.

36 See: ICTY. Judgment of the Trial Chamber in the Kordić and Čerkez case, 26 February 2001, paragraph 401; Judgment of the Trial Chamber in the Blaškić case, 3 March 2000, paragraph 294; Judgment of the Trial Chamber in the Delalić et al, 16 November 1998, paragraph 346; Judgment of the Trial Chamber in the Stakić case, 31 July 2003; Judgment of the Trial Chamber in the Blagojević case, 17 January 2005, paragraph 790. Also: ICTR. Judgment of the Trial Chamber in the Bagilishem case, 7 June 2001, paragraph 38. no evidence to the contrary is given ${ }^{37}$ ), i.e. the ability to prevent the commission of a crime or to punish for it, to take measures to bring criminals to justice ${ }^{38}$, the official position of the accused, even if "actual power" is not determined only by his formal position ${ }^{39}$, the power to give orders and punish for non-compliance ${ }^{40}$, the forces involved (by the commander) in conducting military operations ${ }^{41}$, the power to impose disciplinary measures ${ }^{42}$, the power to control the nomination of personnel ${ }^{43}$, the participation of the accused in negotiations regarding the actions of the troops $^{44}$, etc. $^{45}$

At the same time, the ICTY and the ICTR later began to adhere to the practice of applying a less strict subjective criterion "had reason to know", which implies that the commander has a certain minimum of initial information about the possibility of his subordinates committing

37 See: ICTY. Judgment of the Appeal Chamber in the Delalić et al, 20 February 2001, paragraph 197.

38 See: ICTY. Judgment of the Appeal Chamber in the Blaškić case, 29 July 2004, paragraph 69. Judgment of the Trial Chamber in the Hadžihasanović et al, 15 March 2006, paragraph 82; ICTY. Judgment of the Trial Chamber in the Delalić et al, 20 February 2001, paragraph 252, 266, 302-303.

39 See: ICTY. Judgment of the Trial Chamber in the Kordić and Čerkez case, 26 February 2001, paragraph 418.

40 See: ICTY. Judgment of the Trial Chamber in the Kordić and Čerkez case, 26 February 2001, paragraph 421. Judgment of the Trial Chamber in the Strugar case, 31 January 2005, paragraph 394-396, 406, 408.

41 See: ICTY. Judgment of the Trial Chamber in the Strugar case, 31 January 2005, paragraph 394.

42 See: ICTY. Judgment of the Trial Chamber in the Delalić et al, 16 November 1998, paragraph 767. Judgment of the Trial Chamber in the Strugar case, 31 January 2005, paragraph 406, 408.

43 See: ICTY. Judgment of the Trial Chamber in the Delalić et al, 16 November 1998, paragraph 767. Judgment of the Trial Chamber in the Strugar case, 31 January 2005, paragraphs 404, 411, 413.

44 See: ICTY. Judgment of the Trial Chamber in the Strugar case, 31 January 2005, paragraph 398.

45 See: ICTR. Judgment of the Trial Chamber in Kayishema and Ruzindana case, 21 May 1999, paragraph 229-231, in reference to paragraph 378 of the Judgment of the Trial Chamber in the Delalić et al, 16 November 1998 . 
crimes, and does not provide for responsibility for the inability to obtain such information due to the commander's improper performance of his duties, and the ICC (Article 28 (a)) adheres to the practice of applying the more stringent criterion "should have known". We share the position of the ICC, because otherwise the commanders, in order to evade responsibility, may refer to the impossibility of obtaining information about the illegal behaviour of their subordinates.

Criminal negligence can be in the case when the commander did not know but "should have known" that his subordinates were going to commit, are committing or have committed crimes. In this case, the chief was obliged to be aware of such crimes, checking all the necessary information that could indicate to him the possibility of crimes, and control the actions and behaviour of subordinates. If he ignores this standard of conduct, he acts with gross negligence and is therefore responsible for it (Cassesse, 2003, p. 172; Cassesse, 2008).

We fully share the position of the ICTY, formulated in the Krnoelac and Blaškic cases that if it is impossible to reveal the identity of the direct perpetrators of crimes by name, it is sufficient to identify the unit to which the criminals belonged and show that the accused exercised effective control over this group. ${ }^{46}$ At the same time, several superiors may be responsible for the same crime committed by the same person if it is established that the perpetrator of the crime was at the time of its commission under the command of several commanders. ${ }^{47}$ Moreover,

46 See: ICTY. Preliminary Judgment of the Trial Chamber in the Krnoelac case in a form of indictment act, 24 February 1999, para.46. See also: ICTY. Judgment of the Appeal Chamber in the Blaškić case, 29 July 2004, paragraph 217; Judgment of the Trial Chamber in the Hadžihasanović et al, 15 March 2006, paragraph 90.

47 See: ICTY. Judgment of the Trial Chamber in Krnoelac case, 15 March 2002, paragraph 93; Judgment of as pointed out by the UN International Law Commission, the principle of responsibility of higher officials "applies not only to the immediate superior of a subordinate but also to other higher officials in the military command system or in the state hierarchy, if there are appropriate criteria". 48

Thus, the difference between the doctrine of the commander's responsibility and the doctrine of joint criminal enterprise, as well as cases of execution, order, planning, instigating, aiding and abetting, is that under the doctrine of the commander's responsibility, a person is not a participant in a crime and is only responsible for his own inaction, which in fact is a form of commander's responsibility for his own inaction or omission, in the circumstances, when the International humanitarian law imposes positive obligation to act, and not for the actions of the crime perpetrators. While under the doctrine of the JCE and other types of complicity, a person in one form or another participates in a crime and bears responsibility for this crime. However, the application of the doctrine of commanders' responsibility, in our opinion, is more resource-intensive and ineffective in comparison with the application of the JCE doctrine. The problem is the difficulty of proving the subjective side, the element of "knowledge", and the relationship "chief subordinate". Our opinion is confirmed by the small number of convictions using the doctrine of commanders' responsibility in its pure form, where rare examples are demonstrated, including in the decisions of the ICTY Trial Chamber in the Strugar, Hadžhihasanović et al. ${ }^{49}$ cases and

the Trial Chamber in Blaškić case, 3 March 2000, paragraph 303.

48 See: the project of the Code of Crimes against Peace and Security of Mankind, 1996, Article 6, Commentary, p. 4.

49 See: ICTY. Judgment of the Trial Chamber in the Strugar case, 31 January 2005; ICTY. Judgment of the 
numerous convictions using the JCE doctrine, which has many of the same provisions as the command responsibility doctrine, but without the requirement to establish a chief-subordinate relationship (Grigoryan, 2018, pp. 282-284).

In our opinion, the analysis of the actions of planning, preparing, instigating, abetting, aiding, issuing criminal orders, providing and executing them, depending on the circumstances, despite the fact that they may be qualified with reference to Article 38 of the RA Criminal Code, according to the rules of complicity stipulated by the national legislation, as an organizer, leader, aider and abettor, and in those rare corpus delicti where such a form of participation as an organized criminal group ${ }^{50}$ and criminal association is provided as a qualifying feature, according to the corresponding aggravating factor, in aggregate of crimes, under Article 384 "Aggressive war", part 1 of the Article 387 of the RA Criminal Code "The use of means and methods of war prohibited by an international treaty in military actions or armed conflicts", Article 390 of the RA Criminal Code "Serious violations of the norms of international humanitarian law during armed conflicts", point 13 of the part 2 of the Article 104 of the RA Criminal Code " Murder motivated by national, racial or religious hatred or religious fanaticism", and in some cases under Article 391 "Inaction or issuance of a criminal command during armed conflict" (Grigoryan, 2020, pp. 128-129).

The problem of bringing such persons to criminal responsibility is due to the fact that rep-

Trial Chamber in the Hadžihasanović et al case, 15 March 2006.

50 A crime is recognized as committed by an organized group if it was committed by a stable group of persons who have united in advance to commit one or more crimes. An organized group is distinguished from a group of persons by prior conspiracy by signs of stability and organization. resentatives of the military-political leadership of States do not directly participate in the commission of war crimes, real murders and rapes, do not personally pull the trigger, do not evict anyone, are not present at the places of executions and other crimes, do not personally give orders to commit war crimes, do not sign documents, and crimes are committed far from their offices. Therefore, it would be a paradox to punish only the perpetrators of war crimes, protecting the organizers from criminal responsibility (Gaeta, 2002, p. 983).

Thus, in our opinion, in order to prosecute the commanders of the opposing party of armed conflict, if we do not consider various militaryviolent scenarios, it is necessary to implement the provisions of the Rome Statute of the ICC and the JCE doctrine into the national legislation of the Republic of Armenia, while establishing a special procedure for on war crimes on the basis of the principle of compulsory universal jurisdiction, as well as to organize interaction and cooperation between States, international and national criminal justice bodies, since at present the only international judicial body capable of considering such cases is the International Criminal Court.

In order to ensure these proposals, we propose, among others, to incorporate into Chapter 34 "War Crimes" of Section XIII of the drafted RA Criminal Code the Article 28 of the Rome Statute of the ICC and, in relation to war crimes, develop the types and forms of complicity to the provisions of the JCE doctrine and other types of complicity, i.e. to criminalize such methods of participation in the commission of crimes, when several people have a common criminal purpose, which is realized either jointly or by some members of this group, in accordance with the practice of international criminal justice bodies. 
In addition, in order to identify the persons that should be brought to responsibility, it is necessary to develop a vertical algorithm and establish a military hierarchical connection in the state, as well as a mechanism for transmitting orders downward through officials at all levels along the chain of military instances to the perpetrators of the crime.

It is also necessary to establish this connection in the reverse order, i.e. to establish the perpetrators of the crime, and if it is not possible to reveal the identity of the direct perpetrators by name, it is enough to determine the unit in which he serves and rise through the chain of military instances through different levels of the military hierarchy to the military leadership of the country (soldier, leader of the squad, platoon, company, battalion, regiment, (brigades), divisions (corps), head of the directorate of certain types of troops, commander of the branches and types of troops, Deputy - Chief of the General Staff, Chief of the General Staff, Minister of Defense, etc.).

Thus, in order to hold responsible commanders of the opposing party of armed conflict accountable for committing war crimes, due to legal certainty and evidentiary prospects, national legislation should adopt the positive experience created by the practice of international criminal justice bodies regarding the institution of complicity, the JCE doctrine and the doctrine of command responsibility.

\section{References}

Adelkhanyan, R. (2006). Voenniye prestupleniya $v$ sovremennom mire (Military Crimes in Modern World, in Russian). Moscow: Nauchnaya kniga.

Aldrich, G. (2000). The Laws of War on Land.
American Journal of International Law, 94, 4-41.

Bothe, M. (2002). War Crimes. In A. Cassesse, P. Gaeta, \& J. R. W. D. Jones (Eds), The Rome Statute of the International Criminal Court (pp. 1901-1913). New York: Oxford University Press.

Cassesse, A. (2003). Mezhdunarodnoye ugolovnoye pravo (International Criminal Law, in Russian). Oxford: Oxford University Press.

Cassesse, A. (2008). International Criminal Law $\left(2^{\text {nd }}\right.$ ed.). Oxford: Oxford University Press.

Criminal Code of the Republic of Armenia. (2003, April 29). N LR-528.

Cryer, R. (2005). Prosecuting International Crimes. Selectivity and the International Criminal Law Regime. Cambridge: Cambridge University Press.

Dershowitz, N. (2012). Doktrina "sovmestnikh prestupnikh deystviy" $v$ resheniyakh Mezhdunarodnogo tribunala po bivshey Yugoslavii (Doctrine of "Joint Criminal Enterprise" in Judgments of International Criminal Tribunal for the former Yugoslavia, in Russian). In Mezhdunarodniy Tribunal po bivshey Yugoslavii: Deyatelnost. Rezul'tati. Effektivnost. (International Criminal Tribunal for the Former Yugoslavia: Activities. Results. Effectiveness, in Russian) (p. 23). Moscow: Indrik.

Gaeta, P. (2002). Official Cappacity and Immunities. In A. Cassesse, P. Gaeta, \& J. Jones (Eds), The Rome Statute of the International Criminal Court: A Commentary (p. 983). Oxford: Oxford University Press.

Greenwood, C. (1996). International Humanita- 
rian Law and the Tadic Case. European Journal of International Law, 7, 265283.

Grigoryan, H. (2018). Mezhdunarodno-pravoviye osnovi rassledovaniya voennikh prestupleniy (International-Legal Aspects of Investigation of Military Crimes, in Russian). Yerevan: Europrint.

Grigoryan, H. (2020). Aggression as a Crime in International and National Criminal Law. Wisdom, 1(14), 122-130.

Guskova, E. (Ed.). (2012). Mezhdunarodniy tribunal po bivshey Yugoslavii: Deyatel'nost, rezul'tati, effektivnost' (International Criminal Tribunal for Former Yugoslavia: Activities, Results, Efficiency, in Russian). Materials of International Scientific Conference, 22-23 April, 2009 (p. 544). Moscow: Indrik.

Henkaerts, J-M. \& Doswald-Beck, L. (2005). Customary International Humanitarian Law (Vol. I). Cambridge: Cambridge University Press.

Henkerts, J-M., \& Doswald-Beck, L. (2006). Obichnoye mezhdunarodnoye gumanitarnoye pravo (Customary International Humanitarian Law, in Russian). Norma 113, International Committee of the Red Cross.

ICTY Statute. (1993, 25 May (Res.827(1993)). Retrieved from: https://undocs.org/$\mathrm{ru} / \mathrm{S} / \mathrm{RES} / 827 \% 20 \% 281993 \% 29$.

International Law Commission. (1996). Commentary to Article 7 of the Draft Code of Crimes Against the Peace and Security of Mankind of the 5 July 1996. UN Doc A/51/10. Yearbook of the International Law Commission, Vol. II.
Jones, R. (2000). The Practice of the International Criminal Tribunals for the Former Yugoslavia and Rwanda, Transnational Publishers. Irvington on Hudson.

Kibalnik, A. G., \& Martirosyan, A. S. (2015). Genocid $v$ resheniyakh mezhdunarodnikh tribunalov po Ruande $i$ bivshey Yugoslavii: monografiya (Genocide in judgments of criminal tribunals for Rwanda and former Yugoslavia, monograph in Russian). Moscow: Yurlitinform.

Matveeva, T. (2015). Sotrudnichestvo gosudarstv $v$ borbe s mezhdunarodnoy prestupnostyu - aktualnoye napravleniye sovremennogo mezhunarodnogo prava (Cooperation of States in the Fight Against International Criminality - Actual Sphere of Modern International Law, in Russian). Public and Private Law, 3(27), 54-64.

Poweles, S. (2004). Joint Criminal Enterprise: Criminal Liability by Prosecutorial Ingenuity and Judicial Creativity? Journal of International Criminal Justice, 2(1, 3), 606-619.

Puzireva, Y. (2014). Mezhdunarodniy tribunal po bivshey Yugoslavii: "20 let uspekha?" (International Criminal Tribunal for the Former Yugoslavia: "20 Years of Success?", in Russian). Moscow Journal of International Law, 2(94), 21-36.

UN Commission of Experts. (1992). Final Report. Retrieved from: https://www.icty.org/x/file/About/OTP/un_commission of experts report1994 en.pdf. 